\title{
Erratum: Evaluation of Status of Zinc, Copper, and Iron Levels in Biological Samples of Normal Children and Children with Night Blindness with Age Groups of 3-7 and 8-12 Years
}

\author{
Hassan Imran Afridi • Tasneem Gul Kazi • Naveed Kazi • Ghulam Abbas Kandhro • \\ Jameel Ahmed Baig • Abdul Qadir Shah • Sham Kumar Wadhwa • Sumaira Khan • \\ Nida Fatima Kolachi • Faheem Shah • Mohammad Khan Jamali • \\ Mohammad Balal Arain • Sirajuddin
}

Published online: 22 December 2010

(C) Springer Science+Business Media, LLC 2010

\section{Erratum to: Biol Trace Elem Res \\ DOI 10.1007/s12011-010-8789-8}

The original version of this article unfortunately contained mistakes.

In Table 2, the units of white blood cell count and platelet count should be $\mathrm{K} / \mathrm{mm}^{3}$, while $\mathrm{M} / \mathrm{mm}^{3}$ for red blood cell count.

The online version of the original article can be found at http://dx.doi.org/10.1007/s12011-010-8789-8.

H. I. Afridi • T. G. Kazi • G. A. Kandhro · J. A. Baig • A. Q. Shah • S. K. Wadhwa • S. Khan •

N. F. Kolachi $\cdot$ F. Shah $\cdot$ M. K. Jamali $\cdot$ M. B. Arain $\cdot$ Sirajuddin

National Center of Excellence in Analytical Chemistry, University of Sindh, Jamshoro 76080, Pakistan

T. G. Kazi

e-mail: tgkazi@yahoo.com

J. A. Baig

e-mail: jab_mughal@yahoo.com

F. Shah

e-mail: shah_ceac@yahoo.com

M. K. Jamali

e-mail: mkhanjamali@yahoo.com

M. B. Arain

e-mail: bilal_ku2004@yahoo.com

H. I. Afridi $(\square)$

Mechanical and Manufacturing Engineering, Dublin City University, Dublin, Ireland e-mail: hassanimranafridi@yahoo.com

N. Kazi

Liaquat University of Medical and Health Sciences, 76080 Jamshoro, Pakistan e-mail: tgkazi@yahoo.com 